Benjamin Bossaert

Univerzita Komenského v Bratislave

https://doi.org/10.18485/bgd_nlistiek_30.2018.ch8

\title{
PAUL VAN DEN HEUVEL - DE BRUGFIGUUR TUSSEN ZUIDOOST-EUROPESE EN SLOWAAKSE NEERLANDISTIEK
}

\begin{abstract}
We would like to focus in this contribution on fruitful contacts between the Dutch studies of South Eastern Europe and Bratislava. One figure who played a pivotal role as a key-figure is the focus of attention: drs. Paul van den Heuvel (1952 - 2015). Van den Heuvel came to the former Yugoslavia and established in Ljubljana the second department of Dutch studies, a sustainable chair until today. Later on van den Heuvel moved to Bratislava in 1996, where he helped to establish a curriculum Dutch studies in a five year master programe with all his didactic support. He managed hereby to connect knowledge and ties between the Low Countries, South Eastern Europe and to promote and establish this support in Slovakia too. We would like to place van den Heuvel in a scientific model of a cultural intermediator, based on a multipolar model of Verschaffel, Meylaerts, e.a. (2014). We focus on his personal life, publications and his views on Dutch studies and intercultural contacts. What could be his mission and how could his views be of actual use in a contemporary context of Dutch studies in our Central European region, from Belgrade to Riga?
\end{abstract}

Keywords: intercultural communication, Paul van den Heuvel, South East Europe, Central Europe, Dutch studies, curriculum development

\section{Cultureel bemiddelaars tussen verschillende regio's: een wetenschappelijke inbedding.}

Een scharnierfiguur kan in andere terminologie ook een intercultureel of cultureel bemiddelaar genoemd worden. In deze bijdrage willen we vooral aspecten van de transfer studies en translation studies gebruiken die ons leiden tot een beter begrip van deze intermediators. In feite ontdekte men de bemiddelende instantie bij deze transferprocessen sinds de jaren zeventig van de twintigste eeuw en wordt er ook recent wat meer wetenschappelijke aandacht aan besteed ${ }^{1}$.

1 Zo kunnen we onder meer verwijzen naar de Weense doctoral school die in juli 2017 door de Universiteit Wenen, DCC, de ELTE Boedapest en Comenius, vereniging voor Neerlandistiek in Centraal-Europa werd georganiseerd. Deze school kende een specifieke workshop die onder meer onderzoek stimuleerde naar cultuurbemiddelaars tussen Nederlandse en Centraal-Europese culturen, onder leiding van professor Judit Gera. 
De Hongaarse hoogleraar Nederlandse letterkunde Judit Gera wees ons op de casus Adele Opzoomer, een Nederlands - Hongaarse cultuurbemiddelaar in de negentiende eeuw, die de Hongaarse cultuur dichter bij Nederland bracht. In de negentiende eeuw kon men interessante genderaspecten onderscheiden, aangezien zij de man was van Géza Antál, een Hongaarse theoloog en politicus, door wie zij met de Hongaarse cultuur in contact kwam. Gera gebruikt het multipolaire model van Verschaffel e.a. (2014) en verwijst ook naar Broomans (2012) over multiculturele bemiddelaars. Dit model bepaalt de blik waarmee wij ook naar de figuur van Paul van den Heuvel zullen kijken. We volgen allereerst de definitie van Verschaffel, Meylaers, e.a. (2014). Zij stellen dat een cultureel bemiddelaar een persoon is

[...] die taalkundige, artistieke en politiek-geografische grenzen overschrijdten die culturele uitwisselingen onderneemt. Vooral in een heterogene context, waarverschillende talen en culturele velden op elkaar inwerken zoals in het België vande late negentiende en de eerste helft van de twintigste eeuw.

Een cultureel bemiddelaar als persoon wordt bestudeerd in een kader van biografische gegevens, gekoppeld met interviews en andere getuigenissen die relevant zijn om de mediator te kaderen. Vervolgens kan men verder gaan en in tweede instantie de cultureel bemiddelaar plaatsen in functie van zijn institutionele standpunt, als men beseft dat zijn of haar activiteiten niet als individueel plaatsvonden maar steeds binnen een erkend professioneel netwerk, in lokale of tijdelijke gemeenschappen. Ook in de vertaalwetenschap, vooral dan de descriptieve, wordt aan de vertaler als intermediair een grote rol toegekend door zijn omzetprocessen als een bepaalde categorie of strategie te omschrijven. (Verschaffel e.a. 2014: 1257-1261)

Broomans (2012: 263) hanteert de volgende definitie van een cultuurbemiddelaar:

In mijn werkdefinitie van een cultuurbemiddelaar noem ik verschillende rollen die een cultuurbemiddelaar kan spelen: vertaler, recensent, journalist, letterkundige, literatuurhistoricus, wetenschapper, bibliothecaris, boekhandelaar, verzamelaar, literair agent, scout, uitgever, redacteur van een tijdschrift of bij een uitgeverij, auteur, schrijver van reisverhalen en adviseur.

Het is interessant dat zij nog verder meldt dat haar definitie opgesteld is vanuit de intrede van de professionalisering van de cultuurbemiddeling rond 1900 en dat het een dynamisch concept is (Broomans 2012: 263). Verder laat zij nog een interessant fasenmodel zien, waarbij we kunnen kijken, bij welke fasen Paul van den Heuvel betrokken was als cultuurbemiddelaar. Al in de eerste fase willen wij de suggestie van een docent als bijkomende categorie van cultuurbemiddelaar introduceren als aanvulling voor dit model.

De eerste fase is de ontdekking en introductie van een auteur of literaire tekst door de cultuurbemiddelaar of een groep van cultuurbemiddelaars. Broomans (2012: 
263) vermeldt hier echter niet hoe dit zou kunnen gebeuren. We zouden er kunnen aan toevoegen dat hier ook een rol kan weggelegd zijn voor een docent, een leraar (literatuur) of een academicus. Dit lijkt me een niet te onderschatten factor voor de eerste stap van het bijbrengen van de nodige literaire kennis, als nevencircuit naast de gebruikelijke literaire kringen voor cultuurbemiddeling.

In de tweede fase bevindt de geselecteerde auteur zich in quarantaine. De cultuurbemiddelaar probeert een geïnteresseerd publicatiekanaal (uitgever, theatergezelschap, poëziefestival etc.) te vinden om het werk te publiceren. Een publicatie in een meertalige uitgave of zelfs in het origineel is ook een mogelijkheid.

De verdere fasen, tot en met de zesde in het model van Broomans (2012: 263264), bespreken de verdere weg die vertalingen en teksten uit het brongebied afleggen. Hier komen vooral andere actoren zoals uitgevers en recensenten in een samenspel van verschillende factoren op de voorgrond. Zij zijn verder vooral relevant voor de (al dan niet literaire) artefacten, minder voor de cultuurbemiddelaar(s) die in deze studie centraal staan.

Verschaffel e.a. (2014: 1261) merken bij hun onderzoek ook enkele belangrijke obstakels op, die het onderzoek naar culturele bemiddelaars moeilijk maken en kunnen hinderen: in eerste instantie is het moeilijk een cultureel bemiddelaar exclusief in een rol van vertaler te duwen, aangezien de meesten van hen verschillende rollen bekleed(d)en, als vertaler, schrijver, recencent, (literatuur)wetenschapper, criticus, journalist, leraar, uitgever, ... Daarnaast bekijkt men het cultureel bemiddelen nog te veel als een bipolair model, waarbij men ervan uitgaat, dat de doelcultuur enkel maar ontvangt van de broncultuur en met kennis wordt geïnjecteerd. Deze tweede kritiek werd succesvol in de geschiedenismethodologie aangebracht door Werner en Zimmermann (2003) die als alternatief het begrip histoire croisée (Nederlands: gekruiste geschiedenis) lanceerden. Het gaat hier om een veronderstelling dat men beter de idee van twee gefixeerde naties verlaat, en men zich bewust wordt dat er een proces van wederkerigheid bij het cultuurbemiddelen plaatsvindt, waarbij beide culturen elementen van elkaar doorgeven en vervlocht geraken.

Uiteraard kunnen wij bij Paul van den Heuvel onmogelijk van een bipolaire cultuurbemiddeling spreken: afhankelijk van zijn levensloop, begon hij met zijn Brabantse, Nederlandse achtergrond te doceren over Nederland, maar tegelijk ook over Vlaanderen en raakte respectievelijk betrokken bij de culturen van zowel Slovenië, Italië, Slowakije en Hongarije, maar hij kwam ook via diverse zomercursussen, gastcolleges en collegiale contacten in aanraking met andere culturen van CentraalEuropa (Polen, Tsjechië, ex-Joegoslavië, vervolgens Kroatië en Servië). Dit laat ons volgende, biografische stukje zien. 


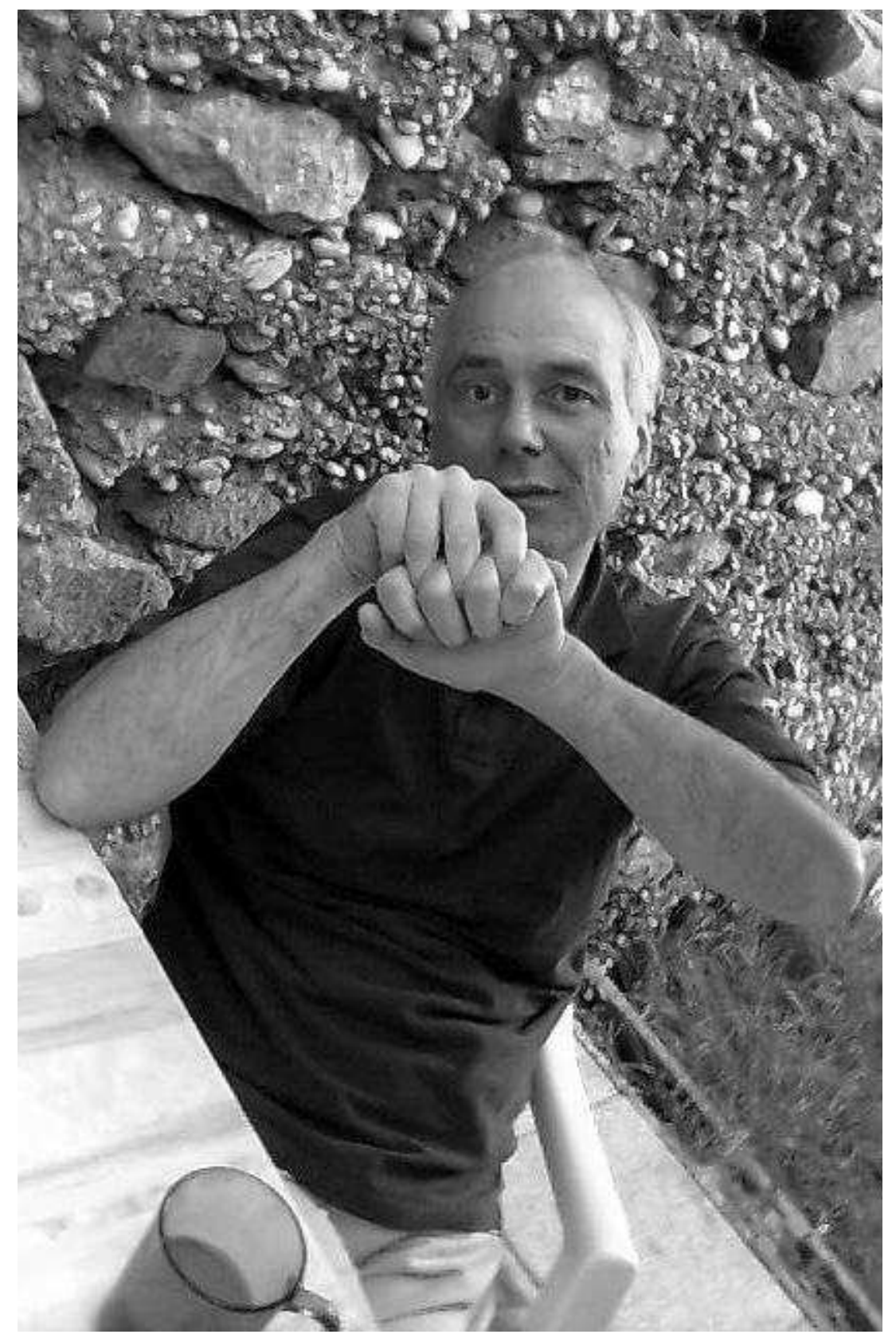

[Afbeelding 1:

Paul van den Heuvel]

\section{Paul van den Heuvel als persoon: korte biografie}

Paul van den Heuvel (afbeelding 1) werd geboren in 1952 in 's Hertogenbosch en studeerde moderne Nederlandse letterkunde en kunstgeschiedenis in Nederland aan de Universiteit Utrecht. Hij legde ook zijn pedagogische bekwaamheidsbewijzen af als docent Nederlands aan dezelfde Universiteit. Van den Heuvel kende als geen ander de internationale neerlandistiek, vooral dan binnen Centraal-Europa, maar ook een beetje daarbuiten: vanuit zijn basis te Ljubljana had hij korte tijd ook een gastlessenreeks in het Italiaanse Trieste, of hij probeerde ook een hoofdvakstudie in te richten in Zagreb, wat uiteindelijk tot enkele gastlessen beperkt bleef. Hij bezocht uiteraard ook de vakgroep Nederlands te Belgrado, de eerste en de grootste in het voormalige Joegoslavië. Dit was eigenlijk het begin van zijn loopbaan in de internationale neerlandistiek. Van den Heuvel kwam op uitnodiging van professor Jelica Novaković-Lopušina voor een gastcollege naar Belgrado in 1989. Daar werden toen plannen ontwikkeld om in de regio zomercursussen te gaan organiseren. Professor Novaković-Lopišina beval hem 
ook aan als lector bij de Universiteit te Ljubljana. Hij koos dus vanaf 1989 voor een verblijf als buitenlands lector Nederlands aan diverse universiteiten in onze regio: de Universiteit te Ljubljana (5 jaar), de Comenius Universiteit te Bratislava (5 jaar) en de Eötvös Loránd (ELTE) Universiteit in Boedapest (1 jaar). (Štefková 2010: 188)

Daarna keerde hij terug naar Nederland, hij koos zijn geboortestad 's Hertogenbosch als thuisbasis en ging terug in Utrecht aan de slag. Hij bleef met een kleine aanstelling verbonden aan het University College te Utrecht. Uit van den Heuvel (2000: 191) vernemen we nog dat hij publiceerde over moderne letterkunde (met name dichtwerk van de Schoolmeester of Jan Hendrik Leopold) en de vertaalactiviteiten van Albert Vigoleis Thelen. Hij zou een proefschrift voorbereid hebben over Rob Nieuwenhuys en de Indische literatuur. We hebben echter geen data gevonden die dit laatste later bevestigen of waar hij dit proefschrift zou verdedigd hebben. Wat ons verder interessant lijkt, is dat van den Heuvel zich in zijn biografie toen omschrijft als „docent neerlandistiek (taalverwerving, letterkunde, kennis land \& volk)“, wat wijst op zijn multi-inzetbaarheid binnen de afdelingen neerlandistiek waar hij werkte.

Naast deze biografische gegevens, zijn er ook nog meer persoonlijke herinneringen bewaard en zowel vanuit Sloveense als Slowaakse bronnen werden er getuigenissen gepubliceerd, bijvoorbeeld door Anita Srebnik (www1) in een passend in memoriam voor Paul van den Heuvel, als in de bundel van Jana Rakšányiová (2016), waar de drie huidige leden van de academische staf hun herinneringen aan Paul als lector neerpennen. Geen enkele laten zijn bijzondere verdiensten voor de neerlandistiek in de hele regio onvermeld, waarbij het duidelijk was, dat van den Heuvel niet enkel lokaalbemiddelde, respectievelijk in Ljubljana, Bratislava en Boedapest op academische bodem, maar ook regionaal, binnen het netwerk van Comenius $^{2}$, dat in de beginperiode toch vooral op enthousiasme en persoonlijke motivatie van enkelen dreef. Daarnaast was Paul van den Heuvel actief als interregionaal bemiddelaar: hij slaagde er in vruchtbare contacten aan te knopen met onder andere de Nederlandse Taalunie, het Prins Bernhard Cultuurfonds en de Nederlands-Vlaamse culturele organisatie de Orde van den Prince en wellicht ook met de diplomatieke instellingen, ambassades van Nederland, België en de Vlaamse vertegenwoordigingen. Deze Nederlands-Vlaams-Midden-Europese contacten zijn en blijven de hoeksteen van elke succesvolle afdeling Nederlands in de regio Centraal-Europa. Paul van den Heuvel stond niet graag op foto's, maar uit onze archieven in Bratislava, tonen we er toch graag twee: eentje voor de ingang van de faculteit samen met zijn eerste generatie studenten neerlandistiek, de generatie die studeerde van 1996 tot 2001, vervolgens ter vergelijking de laatste foto bij zijn bezoek aan de Comenius Zomercursus te Bratislava in 2014 met enkele collega-docenten (afbeelding 2 en 3).

2 Comenius werd volgens de website opgericht in 1995 in Olomouc en heropgericht in 1999 als Nederlandse vereniging. Paul van den Heuvel voerde in de regionale vereniging een functie uit als bestuurslid. https:// comenius.ned.univie.ac.at/ De huidige website wordt dit jaar geactualiseerd. Volgens professor Jelica Novaković-Lopušina werden tijdens een van de vergaderingen die in Wenen werd gehouden met z'n allen op Pauls initiatief persiflages op het gedicht "Ik ben een God in het diepst van mijn gedachten" gemaakt in cafe Central. 


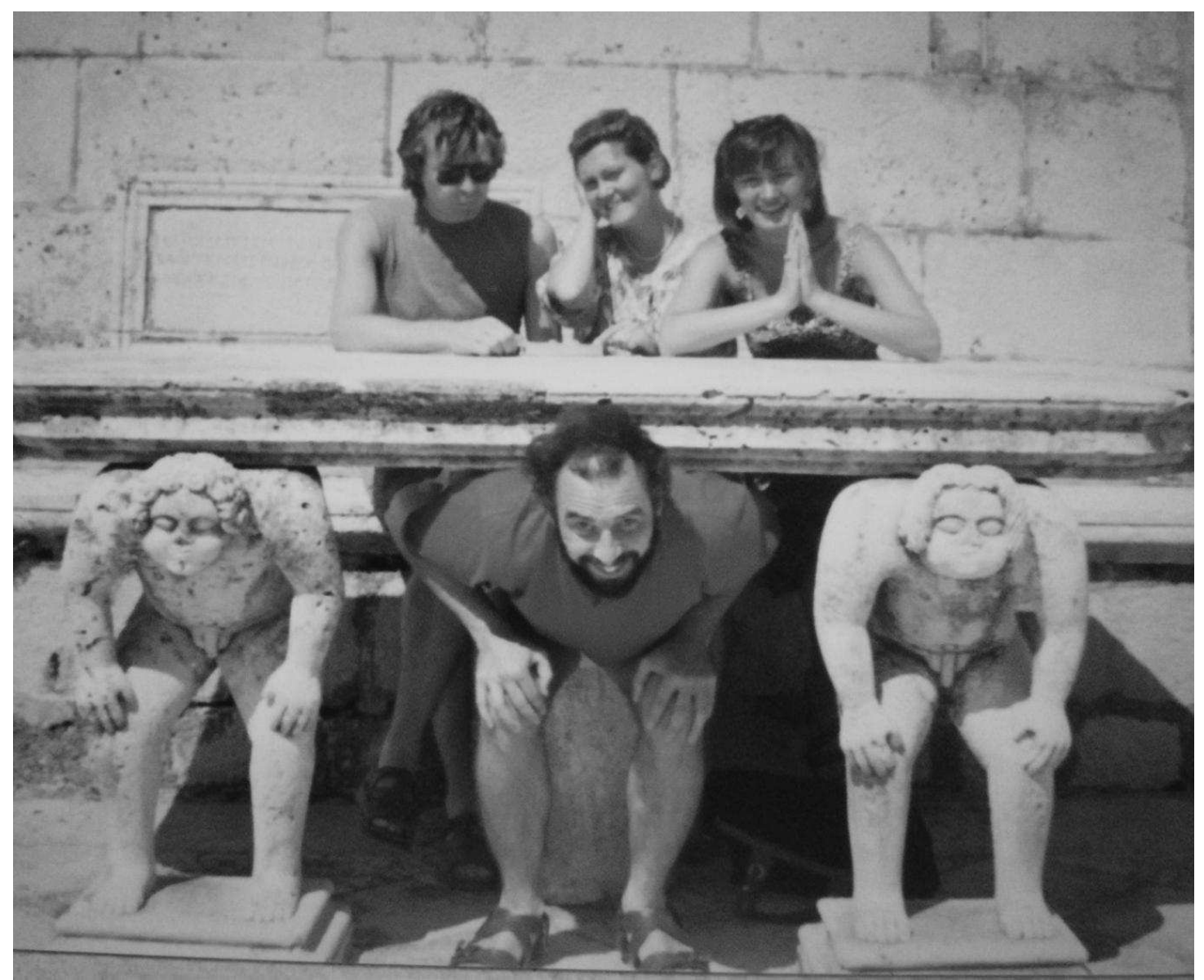

[Afbeelding 4: Zomercursus Herceg Novi. Paul van den Heuvel onder de tafel, aan tafel v.l.n.r. Will Tinnemans, Aleksandra Vojinović en Jelica Novaković-Lopušina.]

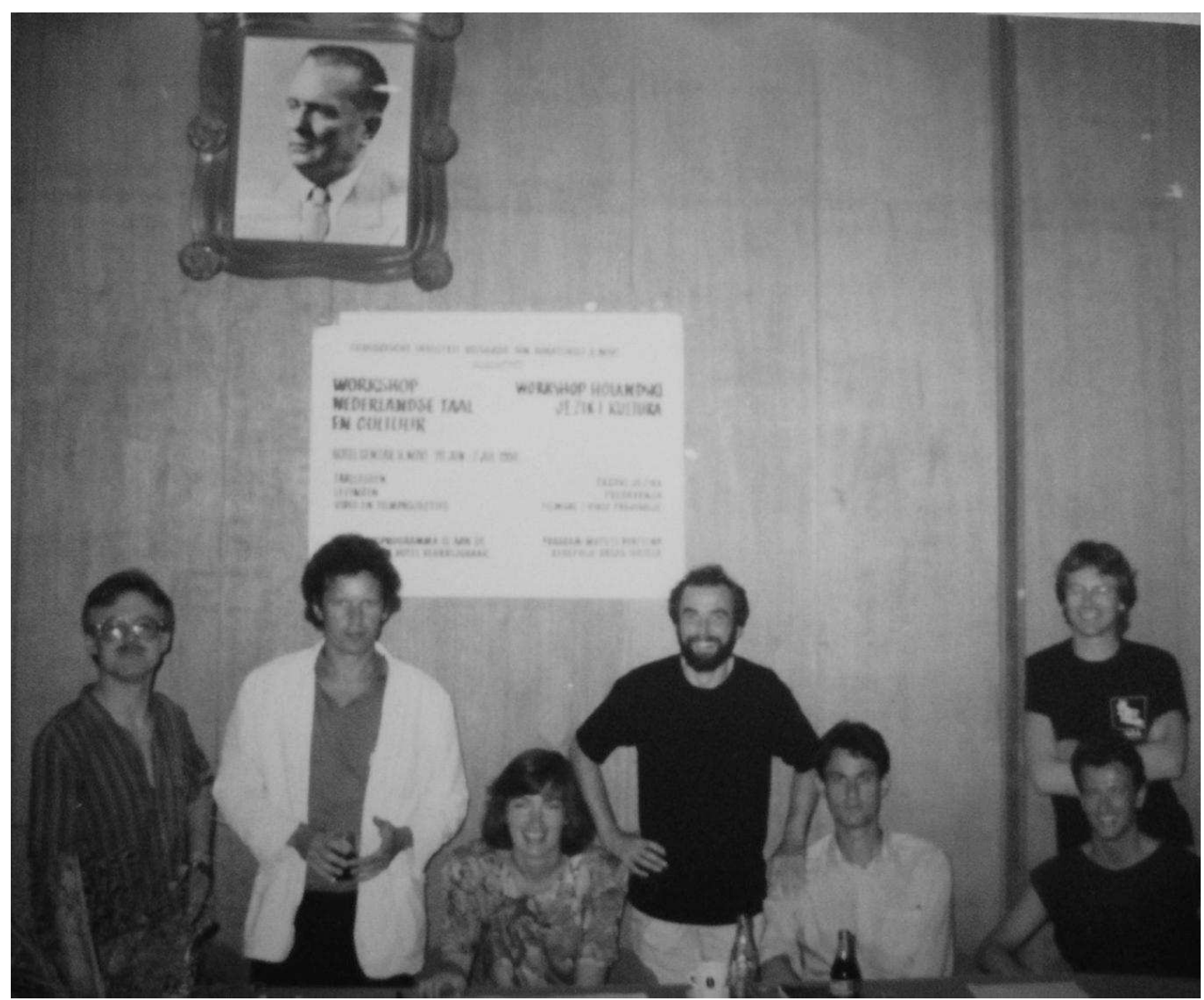

[Afbeelding 5: Zomercursus Herceg Novi: Leo Van Acht, x, Jelica Novaković, Paul van den Heuvel, Charles van Leeuwen, Will Tinnemans, Sjaak van Vlerken.] 
We dienen ook nog te vermelden dat Paul van den Heuvel zowel in Slovenië als in Slowakije veel aan curriculumontwikkeling heeft gewerkt, om in deze landen een degelijke opleiding tot neerlandicus te ontwikkelen. In Ljubljana in Slovenië bestaat de studie Nederlands nog steeds als vak binnen de studie Germanistiek en in Bratislava, Slowakije, als hoofdvakstudie binnen een tweevakprofiel vertalen en tolken Nederlandse taal en cultuur, met een vijfjarige master complex geaccrediteerd.

Srebnik vermeldt ook nog dat Paul van den Heuvel zich actief inzette om neerlandici van de regio te verbinden met behulp van regionale zomercursussen en vermeldt internationale cursussen in Herceg Novi, Montenegro en Piran, Slovenië (www1). Samen met docent Charles van Leeuwen werden toen in de Zuidelijke regio samen met de Italiaanse neerlandistiek samenwerkingen opgezet.

Zowel Rakšányiová (2016: 19) als Srebnik (www1) schrijven bovendien over zijn buitengewone logistieke inspanningen waarbij het uitbouwen van deze afdelingen neerlandistiek met een degelijk uitgeruste bibliotheek zeker bijdroegen tot een betere cultuurverspreiding. Nog steeds bouwen de huidige collecties voor een groot stuk voort op het werk van hun pioniers en de eerste medewerkers ${ }^{3}$.

Al deze activiteiten die van den Heuvel ontwikkelde, konden uiteraard niet verstoken blijven van een onderbouwde visie die hij had over de neerlandistiek. Naast de biografische kant van ons verhaal, willen wij ons nu concentreren op de institutionele kant van het verhaal.

\section{Publicaties en visie: een interculturele neerlandistiek}

Zoals we al konden merken, was Paul opgeleid als letterkundige, maar kende hij ook zijn kunstgeschiedenis en hieruit kunnen we al meteen merken dat zijn aandacht en interesse verdeeld werd over meerdere vakgebieden. Deze aanpak kwam direct ook van pas bij zijn pionierswerk bij het helpen oprichten van verschillende afdelingen Nederlands. Uit zijn biografie (cfr. supra) blijkt interesse voor Nederlandse poëzie (De Schoolmeester, Leopold) en ook op latere leeftijd publiceerde hij nog af en toe over dichtkunst, zoals bijvoorbeeld twee Nederlandstalige vertalingen van een rondeel van Charles d'Orléans ${ }^{4}$. Daarnaast stellen we vast dat hij in zijn letterkundige publicaties, naast zijn aandacht voor poëtica, literair-technische aspecten en tekstuele elementen, nooit de aandacht verloor voor vertalen, cultuurtransfer en een breder overzicht, een bredere context. Daarvan getuigt bijvoorbeeld zijn overzicht van Nederlandstalige literaire tijdschriften in de Slovak review in 1997 als editor $^{5}$, of een nummer met

3 Zo merken we de bijzonder goed uitgebouwde sectie letterkunde en geschiedenis op van de bibliotheek te Bratislava, onder meer aangekocht door Abram Muller, professor Adam Bžoch en Paul van den Heuvel, aangevuld door publicaties in het veld van de (Tsjecho-)Slovaakse vertaalkunde door Jana Rakšányiová.

4 Zie hiervoor Heuvel (2010) in Štefková (2010).

5 Zie hiervoor bijvoorbeeld Heuvel, Paul van den, 1997. Literárnovedné časopisy v Nizozemsku a vo Flámsku. pp. In: Slovak Review, vol. VI, n.2. Bratislava: Institute of World Literature Slovak Academy of Sciences. In dit nummer fungeerde Paul van den Heuvel samen met professor dr. Adam Bžoch, germanistneerlandicus, literatuurwetenschapper als guest editor van een nummer gewijd aan dwarsverbanden tussen de Slowaakse en Nederlandstalige literatuurwetenschap. 
vertalingen uit Belgische literatuur in het Slowaakse tijdschrift Revue svetovej literatúry dat hij mede bloemgelezen heeft en de vertalingen begeleidde. Dat deed hij zelfs nog op latere leeftijd, toen hij naast enkele gastcolleges met enkele enthousiaste vertaalsters een poëzieworkshop in Bratislava rond gedichten van Anton Korteweg mee begeleidde met deskundig commentaar. Deze gedichten werden later effectief gepubliceerd in het literaire tijdschrift, waardoor men zou kunnen zeggen, dat in het model van Broomans (2012: 263) van den Heuvel wel degelijk betrokken was bij de eerste fasen van de cultuurbemiddeling, weliswaar niet als vertaler zelf.

Een duidelijke visie over wat neerlandistiek zou kunnen inhouden vinden we in een artikel dat werd gepubliceerd als resultaat van een wetenschappelijke conferentie te Bratislava (Van den Heuvel 2000). Hier vinden we enkele belangrijke opmerkingen van Paul, waarbij hij een specifiek profiel schetst van wat men toen nog meestal de neerlandistiek extra muros noemde, een term die vandaag meer en meer vervangen wordt door te spreken van de Internationale neerlandistiek of vanuit didactisch oogpunt het vak Nederlands als Vreemde Taal (Fenoulhet en Renkema $2010^{6}$ ). We vatten ze voor het gemak samen in enkele punten. Aangezien het thema van de conferentie interculturaliteit was, stelt hij voor wat deze interculturaliteit aan de Comenius Universiteit te Bratislava betekent; ze is ingebed in een raamwerk van germanistiek en scandinavistiek en heeft dus bij voorbaat al te maken met snijpunten van verschillende culturen. Daarnaast geeft hij aan dat naast een klassieke taal- en letterkunde men ook niet de interculturele competentie van een student in de regio Midden- Europa mag vergeten, aangezien deze sowieso geboren is in een cultuur die anders is dan het te bestuderen gebied. Hij geef ook een aanzet van hoe dat vak cultuurkunde inhoudelijk dan zou moeten gefundeerd worden ${ }^{7}$ (Heuvel 2000: 32). Van den Heuvel poneert in een eerste slotopmerking dat een neerlandistiek in een curriculum duidelijk moet maken dat zij anders is dan een intra murosneerlandistiek, omdat deze culturele diversiteit inherent is aan de opleiding in het buitenland. Verder pleit hij ook voor een een grote multi-inzetbaarheid onder docenten neerlandistiek en merkt hij op dat vele jonge neerlandici nog zullen doorgroeien in hun expertise, zowel qua onderwijs- als onderzoeksactiviteiten. Zijn volgende opmerking is dat een moedertaalspreker in elke vakgroep een conditio sine qua non zou moeten zijn, om een Nederlandse of Vlaamse stem te blijven horen, als aanvulling of tegenhanger voor de stem uit het land zelf, wat dan automatisch de pluriformiteit verhoogt (Heuvel 2000: 35).

6 Fenoulhet en Renkema (2010) betogen in hun inleiding van hun publicatie dat de termen intra en extra muros beter zouden vervangen worden door de term internationale neerlandistiek, die geen expliciet of impliciet waardeoordeel zou inhouden, maar eerder de internationale samenwerking van de neerlandici in de verf kan zetten, en verder dan, als het moet, te spreken van binnenlandse en buitenlandse neerlandistiek.

7 Hij bedacht dat eigenlijk cultuurkunde als soort van containerbegrip zou kunnen gelden, gaande van kantklossen over voetbal tot (schilder)kunst en eigenlijk alles, wat niet direct verbonden is met taal- en/ of letterkunde, maar eerder met het cultuureigen van de Lage Landen. Dit begrip kan dan ofwel als een apart vak of als component in een taalverwervingsmethode ingebouwd worden. 
Als laatste punt hoopt van den Heuvel (2000:36) dat met bijeenkomsten en besprekingen over pluriformiteit en interculturele competentie er een tegengewicht geboden wordt binnen een steeds nauwer samenwerkend Europa. Hij pleit ook voor een culturele dialoog die een tegenhanger zou moeten worden voor het economische denken wat in de politieke wereld prioriteit krijgt.

We kunnen ons nu de vraag stellen, in hoeverre de standpunten van Paul van den Heuvel de tand des tijds doorstaan hebben of, door ze nog eens in herinnering te brengen, bij de huidige afdelingen neerlandistiek een vruchtbare bodem kunnen vinden.

\section{Interculturaliteit anno 2017: welke standpunten blijven overeind?}

Uiteraard heeft de ontwikkeling van de neerlandistiek als discipline in de regio Midden-Europa sinds 2000 niet stilgestaan en dus is het interessant om eens te kijken welke belangrijke stappen en evoluties er zijn gezet in de richting van interculturaliteit zoals Van den Heuvel het in zijn visie neerzette. Als we enkele karakteristieke ontwikkelingstendensen schetsen voor de regio Centraal-Europa, dan kunnen we het model dat de Poolse neerlandicus Stanisław Prędota (2008: 37) beschreef verder aanvullen (Bossaert 2017).

Prędota heeft het over een beginfase (sinds eind jaren tachtig en de vroege jaren negentig, cfr. het lectoraat in Belgrado dat in 1987 werd opgericht) die voornamelijk in het teken stond van taaldidactische activiteiten van docenten Nederlands in Centraalen Oost-Europa. Bovendien konden we ook een ware stichtingsijver merken. Centra neerlandistiek die al langer bestonden in bijvoorbeeld Boedapest, Wrocław, Praag en Wenen werden aangevuld met het opstarten van nieuwe lectoraten, hoofd- en bijvakstudies in Bratislava, Debrecen, nogmaals Boedapest,Belgrado, Vilnius, Brno, Olomouc, enzovoort. De Nederlandse Taalunie bracht werkbezoeken en beloofde ook materiële steun. Leermiddelen, vertaalwoordenboeken en grammatica's werden ontwikkeld als ondersteuning van de contrastieve studie van Nederlands met de lokale talen. Naast stichtingsijver konden enkele docenten, die als enige staflid op hun afdeling Nederlands doceerden, niet anders dan de eerste samenwerkingsverbanden aangaan, getuige hiervan is Comenius, het netwerk voor neerlandici in Centraal- (en toen nog Oost-) Europa.

De neerlandistiek mat zich trouwens hierbij ook een profiel aan, dat zich stilaan begon te onderscheiden van wat men de neerlandistiek intra muros, namelijk in België en in Nederland, placht te noemen. Curricula in onze regio waren vooralsnog in grote mate gestoeld op de klassieke programma's Nederlandse taal- en letterkunde zoals ze aan grotere universiteiten (Gent, Leuven, Leiden, Amsterdam) voorkwamen als klassieke Germaanse filologie.

De tweede fase noemt Prędota (2008: 38) de uitbouwfase. Het is moeilijk om deze fase precies in een tijdsspanne te situeren, omdat er bijvoorbeeld nog steeds nieuwe lectoraten en/of vakgroepen zouden ontstaan en hun opleiding uitbouwen (bijvoorbeeld Zagreb), maar laten we bijvoorbeeld de verzelfstandiging van een 
aparte vakgroep neerlandistiek in Olomouc in 2003 (Engelbrecht 2008: 142) een soort ijkpunt noemen. In elk geval gaat de uitbouwfase gepaard met een intensivering van wetenschappelijke activiteit in de regio. Dat lijkt logisch: na de beginfase zijn ook enkele talentvolle neerlandici opgeleid die interesse tonen in de derde cyclus van het doctoraats- of promotieonderzoek en zij elkaar gaan ontmoeten op regionale en internationale colloquia. Dat is een eerste graadmeter van intensivering van wetenschappelijk onderzoek. De tweede graadmeter kan het oprichten van enkele wetenschappelijke tijdschriften zijn. Neerlandica Wratislavensia had een langere traditie, maar onder meer AMOS (van het netwerk Comenius) ontstaat, Werkwinkel komt uit in Poznań, Acta neerlandica in Debrecen, Karoli studies, S.N.C.U.B. in Bratislava en dergelijke meer. Kenmerkend is hierbij ook dat er een wetenschappelijke profilering komt van de instituten: neerlandistiekafdelingen in de regio krijgen hun eigen specialismen, hun onderzoek waarbij ze sterke punten ontwikkelen en een eigen gezichtkrijgen. Samenwerkingsverbanden worden geïntensiveerd: de Comenius Zomercursus wordt opgericht, er worden naast regionale colloquia ook doctorandien habilitandicolloquia georganiseerd.

Ondertussen zijn we aanbeland bij een 'vervel-' of ontpopfase. De neerlandistiek in onze regio moet zich door externe en interne factoren ontpoppen naar andere levensvatbare vormen. Sommige afdelingen staan onder druk van hun faculteiten zelf, als kleine talenstudies: er wordt gekort op arbeidscontracten en plaatsen, ook al schermen de collega's neerlandistiek als tegenargument met de niet-aflatende steun van de Taalunie. Tegelijk komt er externe druk: de Taalunie komtbijvoorbeeld in 2015 zelf in politiek Nederland in woelig vaarwater, hun activiteiten worden in vraag gesteld en men moet zich voor ondersteuning aan Nederlands in het buitenland steeds meer en meer verantwoorden. Door meerdere kritische rapporten werd de Taalunie doorgelicht.Het aantal panelgesprekken en discussiefora, bijvoorbeeld op sociale media, op conferenties waarbij over de toekomst van talenstudies wordt gesproken en gediscussieerd, waarbij een neerlandistiek in onze regio zichzelf telkens weer moet verantwoorden, is niet meer bij te houden. Inmiddels werden enkele aangekondigde bezuinigingen van de Taalunie weliswaar teruggeroepen, maar waakzaamheid blijft geboden.

Andere internefactoren nopen soms ook tot denkwerk: in Tsjechië en Slowakije constateren we bijvooorbeeld dalende studentenaantallen, deels om demografische redenen, deels omwille van een algemene dalende trend met minder interesse in de humanities, studenten die op zoek zijn naar economische werkzekerheid en minder in een interessestudie. Dat zorgt voor aanleidingen om curricula te laten 'vervellen' of ontpoppen naar andere levensvatbare vormen. Met enkel materiële steun van Taalunie, ambassades en dergelijke organisaties en individuele werkkracht alleen lukt het niet meer. In de komende decennia moeten we meer en meer denken in termen van samenwerkingsverbanden en het uitwisselen van (vooral wetenschappelijke en didactische) kennis om ons op die manier te wapenen tegen dreigende sluiting of het verdwijnen van de studies omdat we een kleine afdeling zouden zijn (Bossaert 2017).

Peilers die gebleven zijn in de geest van de visie van Paul van den Heuvel, is de politiek van de Nederlandse Taalunie om één moedertaalspreker per afdeling 
financieel te ondersteunen met een suppletie op een lokaal salaris. Daarnaast is de bredere aandacht voor wetenschap naast onderwijs ook meer en meer een feit in de neerlandistiek in de regio: we kennen met regelmaat $b(1)$ oeiende colloquia voor doctorandi en habilitandi, naast grotere regionale colloquia onder de auspiciën van Comenius en de Nederlandse Taalunie. Hoe de diverse afdelingen neerlandistiek zijn omgegaan met de notie interculturaliteit is een ander aspect. In Bratislava is bijvoorbeeld de vakinhoud voor interculturele communicatie gaandeweg veranderd, maar Kennis van land en volk (als vak) blijft in de bachelorfase een belangrijke component vormen van het cultuurcurriculum ${ }^{8}$. Een mogelijke uitbouw van dwarsverbanden tussen germanistiek, anglistiek en neerlandistiek, om een tweede voorbeeld te noemen, werd sinds dit academiejaar gerealiseerd in een keuzevak voor germanisten dat Dutch as reading knowledge, Nederlands als derde taal aanbiedt, met voldoende taalkundige en culturele achtergrondinformatie om germanisten en anglisten in te leiden in de wereld van de neerlandistiek en hen uitnodigt om parallellen te ontdekken. Daarnaast blijft het een focus van onze regionale neerlandistiek en het samenwerkingsplatform Comenius om verder duurzame projecten te ontwikkelen voor studenten en docenten.

\section{Besluit}

Hoewel Paul van den Heuvel volgens de modellen van Broomans (2012) en Verschaffel e.a. (2014) niet volledig in het kader van hun definitie als cultureel bemiddelaar past, zouden we toch willen stellen dat hij onmiskenbaar zijn plaats had in een multipolair model van cultuurbemiddeling en wel in de eerste plaats als docent (leraar) taalverwerving in combinatie met cultuur en letterkunde, daarnaast als literatuurwetenschapper, maar wellicht nog belangrijker als inspiratiebron voor velen op menselijk vlak. Dankzij zijn enthousiasme slaagde hij er in hartelijke contacten te onderhouden tussen zijn Nederlandse, Vlaamse, Sloveense, Kroatische, Slowaakse en Servische collega's en zorgde aldus voor wederzijdse culturele contacten, door generaties van neerlandici een basisopleiding neerlandistiek aan te bieden in een stevig curriculum. Dankzij zijn inspanningen verschenen er ongetwijfeld enkele talentvolle (al dan niet literaire) vertalers, gidsen, academici en andere enthousiastelingen die verder aan cultuurbemiddeling doen tussen Zuidoost-Europa, Centraal-Europa en de Lage Landen. Hij is daarom een kleine schakel in het succes van drie decennia neerlandistiek in Belgrado en Zuidoost-Europa.

8 Vergelijk hiervoor Bossaert 2015 http://www.nizozemscina.si/sl/obvestila/01-07-2015/umrl-je-paul-vanden-heuvel-ustanovitelj-lektorata-za-nizozemski-jezik-kulzuto 


\section{Literatuuropgave}

Bossaert, Benjamin. 2015. 'Teaching Flemish-Dutch culture and literature within Slovak translation studies.' Engelbrechtová, J. (ed.) Dutch-Flemish-Central European Relations. Chapters from cultural relations between North-West- and East-Central Europe volume 7. Olomouc: Univerzita Palackého v Olomouci.

Bossaert, Benjamin. 2017. 'De complexe accreditatie van 2014 te Bratislava: een update van het curriculum.' In: Acta Neerlandica, Debrecen (in druk).

Broomans, Petra. 2012. 'Zichtbaar in de canon. Spelregels voor cultuurbemiddelaars.' In: Tijdschrift voor Nederlandse Taal-en Letterkunde. 128.

Engelbrecht, Wilken, Hamers, Bas, Kř́žová, Kateřina (eds.). 2008. Neerlandica III. Aspecten van de extramurale neerlandistiek. Acta Universitatis Palackianae Olomoucensis Facultas Philosophica Neerlandica 3. Olomouc: Univerzita Palackého v Olomouci.

Fenoulhet, Jane, en J. Renkema. 2010. Internationale Neerlandistiek : Een Vak In Beweging. Gent: Academia Press.

Heuvel, Paul van den. 1997. 'Literárnovedné časopisy v Nizozemsku a vo Flámsku.' In: Slovak Review, vol. VI, n.2. Bratislava: Institute of World Literature Slovak Academy of Sciences.

Heuvel, Paul van den (ed.). 2000. Interculturaliteit. Interculturele aspecten van de Neerlandistiek in Midden- en Oost-Europa. Bratislava: Stimul.

Heuvel, Paul van den. 2000. 'Het specifieke karakter van de studie Nederlands extra muros. Pleidooi voor een interculturele neerlandistiek.' In: Heuvel, Paul van den (ed.), 2000. Interculturaliteit. Interculturele aspecten van de Neerlandistiek in Midden- en Oost-Europa. Bratislava: Stimul.

Heuvel, Paul van den. 2010. 'Het rondeel der rondelen. Twee Nederlandse vertalingen van Charles d'Orléans' „Le temps a laissié som manteau.“' In: Štefková, Marketa (ed.), 2010. Vizie Translatologie. Album amicorum pre Janu Rakšányiovú. Studia Nederlandistica Universitatis Comenianae Bratislavensis opus 10. Bratislava: oddelenie nederlandistiky, FF UK Bratislava.

Prędota, Stanisław. 2008. 'Neerlandica in Midden- en Oost-Europa.' In: Engelbrecht, W., Hamers, B., Křížová, K. (eds.) Neerlandica III. Aspecten van de extramurale neerlandistiek. Acta Universitatis Palackianae Olomoucensis Facultas Philosophica Neerlandica 3. Olomouc: Univerzita Palackého v Olomouci.

Rakšányiová, Jana. 2016. Nederlandistika na Slovensku. Studia Nederlandistica Universitatis Comenianae Bratislavensis opus 10. Bratislava: oddelenie nederlandistiky, FF UK Bratislava.

Štefková, Marketa (ed). 2010. Vizie Translatologie. Album amicorum pre Janu Rakšányiovú. Studia Nederlandistica Universitatis Comenianae Bratislavensis opus 10. Bratislava: oddelenie nederlandistiky, FF UK Bratislava. 
Verschaffel Tom, Meylaerts Reine, Lobbes Tessa, et al. 2014. 'Towards a Multipolar Model of CulturalMediators within Multicultural Spaces. Cultural Mediators in Belgium, 1830-1945'. In: Revue belge de philologie etd'histoire, tome 92, fasc. 4. Histoire médiévale, moderne et contemporaine Middeleeuwse, moderne enhedendaagse geschiedenis. pp. 1255-1275.

Werner, Michael \& Zimmermann, Bénédicte. 2003. 'Beyond Comparison : Histoire Croisée and the Challenge of Reflexivity.' In: Annales HSS, Jan.-Feb. 58, 1, pp. 7-36.

\section{Internetbronnen}

www1

Anita Srebnik. Umrl je Paul van den Heuvel. Online. Geraadpleegd op 29 october 2017 van http://www.nizozemscina.si/nl/obvestila/01-07-2015/umrl-je-paul-van-denheuvel-ustanovitelj-lektorata-za-nizozemski-jezik-kulzuto [deze pagina bestaat niet meer] 